Fl udar abi ne- Medi at ed Ci r cunvent $i$ on of Cyt ar abi ne Resi st ance Is Associ at ed wi th Fl udar abi ne Tri phosphate Accumul at i on in Cyt ar abi ne- Resi st ant Leukemi c Cel Is

\begin{tabular}{|c|c|}
\hline 著者 & $\begin{array}{l}\text { Yamantot o Shuj i, Yamauchi Takahi ro, Kawai } \\
\text { Yasukazu, Takemur a Har uyuki, Ki shi Shi nj i, } \\
\text { Yoshi da Aki ra, Urasaki Yoshi masa, I wasaki } \\
\text { H r omi chi, Ueda Takanor i }\end{array}$ \\
\hline $\begin{array}{l}\text { jour nal or } \\
\text { publ i cati on title }\end{array}$ & I nt er nat i onal J our nal of Hemat ol ogy \\
\hline vol une & 85 \\
\hline nunber & 2 \\
\hline page $r$ ange & $108-115$ \\
\hline year & $2007-02$ \\
\hline URL & ht t p: //hdl . handl e. net /10098/1086 \\
\hline
\end{tabular}




\title{
Fludarabine-Mediated Circumvention of Cytarabine Resistance Is Associated with Fludarabine Triphosphate Accumulation in Cytarabine-Resistant Leukemic Cells
}

\author{
Shuji Yamamoto, Takahiro Yamauchi, Yasukazu Kawai, Haruyuki Takemura, Shinji Kishi, \\ Akira Yoshida, Yoshimasa Urasaki, Hiromichi Iwasaki. Takanori Ueda \\ Department of Hematology and Oncology, University of Fukui, Fukui. Japan
}

Received September 6, 2006; received in revised form Oclober 15, 2006; accepted November 6, 2006

\begin{abstract}
The combination of cytarabine (ara-C) with fludarabine is a common approach to treating resistant acute myeloid leukemia. Success depends on a fludarabine triphosphate (F-ara-ATP)-mediated increase in the active intracellular metabolite of ara-C, ara-C 5'-triphosphate (ara-CTP). Therapy-resistant leukemia may exhibit ara-C resistance, the mechanisms of which might induce cross-resistance to fludarabine with reduced F-ara-ATP formation. The present study evaluated the effect of combining ara-C and fludarabine on ara-C-resistant leukemic cells in vitro. Two variant cell lines ( $R 1$ and $R 2$ ) were 8 -fold and 10-fold more ara-C resistant, respectively, than the parental HL-60 cells. Reduced deoxycytidine kinase activity was demonstrated in R1 and R2 cells, and R2 cells also showed an increase in cytosolic $5^{\prime}$-nucleotidase II activity. Compared with HL-60 cells. R1 and R2 cells produced smaller amounts of ara-CTP. Both variants accumulated less F-ara-ATP than HL-60 cells and showed cross-resistance to fludarabine nucleoside (F-ara-A). R2 cells, however, accumulated much smaller amounts of F-ara-ATP and were more F-ara-A resistant than R1 cells. In HL-60 and R1 cells, F-ara-A pretreatment followed by ara-C incubation produced F-ara-ATP concentrations sufficient for augmenting ara-CTP production, therehy enhancing ara-C cytotoxicity. No potentiation was observed in $\mathrm{R} 2$ cells. Nucleotidase might preferentially degrade $\mathrm{F}-\mathrm{ara}$ - $\mathrm{A}$ monophosphate over ara-C monophosphate, leading to reduced F-ara-ATP production and thereby compromising the $\mathrm{F}$-ara-A-mediated potentiation of ara-C cytotoxicity in $\mathrm{R} 2$ cells. Thus, F-ara-A-mediated enhancement of ara-C cytotoxicity depended on F-ara-ATP accumulation in ara-C-resistant leukemic cells but ultimately was associated with the mechanism of ara-C resistance.
\end{abstract}

Int $J$ Hematol. 2007;85:108-115. doi: 10.1532/IJH97.06177

(C) 2007 The Japanese Society of Hematology

Key words: Ara-C; F-ara-A; Drug resistance; Leukemia; FLAG

\section{Introduction}

Cytarabine (1- $\beta$-D-arabinofuranosylcytosine) (ara-C), it pyrimidine nucleoside analogue, is among the most elfective anticancer agents in both induction and salvage chemotherapies for acute myeloid leukemia [1,2]. The first step in the mechanism is the transportation of ara-C into leukemic cells by membrane transporters, including the human

Correspondence and reprint requests: Takahiro Yamauchi, MD, PhD, Department of Hematology and Oncology, University of Fukui, 23 Shimoaizuki, Matsuoka, Fukui 910-1193, Japan; 81-776-61-3111; fax: 81-776-61-8109 (c-mail: tyamauch@fmsrsa.fukui-med.ac.jp). equilibrative nucleoside transporter 1 (hENT1) [3]. Ara-C is then phosphorylated to ara-C 5'-monophosphate by deoxycylidine kinase, the rate-limiting enzyme, and subsequently to ara-C 5'-triphosphate (ara-CTP) [4-7]. Ara-CTP is partly incorporated as a monophosphate into DNA strands during the $S$ phase of the cell cycle [6,7]. Drug incorporation into DNA inhibits the extending primer from lurther incorporation of deoxyribonucleotides, including deoxycytidine triphosphate (dCTP), thereby inhibiting DNA synthesis [8-10]. Because the amount of drug incorporated into DNA is the product of the ara-CTP concentration and time, araCTP is an index of ara-C cytotoxicity $\mid 8-10]$. The clinical application of this index was established by documenting a correlation between the intracellular pharmacokinetics of ara-CTP and the response to ara- $C$ therapy [11-14]. Thus, 
in vitro and clinical studies have suggested the utility of therapeutic strategies that augment ara-CTP production in leukemic blasts.

One strategy that increases the intracellular ara-CTP concentration is pretreatment with the purine nucleoside analogue fludarabine (9- $\beta$-D-arabinofuranosyl-2-fluoroadenine 5'-monophosphate) [15-17]. Fludarabine nucleoside (F-ara-A) is taken up by leukemic cells and is phosphorylated into the active form, fludarabine 5 -triphosphate (F-ara-ATP), through the pathway common to ara-C [18]. F-ara-ATP stimulates deoxycytidine kinase in 2 ways, thereby enhancing ara-CTP production. The first is a direct effect on deoxycytidine kinase. The second effect is indirect and is mediated through the inhibition of ribonucleotide reductase, an enzyme responsible for the de novo synthesis of deoxyribonucleotides [19]. The inhibition of ribonucleotide reductase produces a decline in the intracellular dCTP pool, thereby decreasing dCTP-mediated leedback inhibition of deoxycytidine kinase [15-17]. In both cases, the intracellular F-ara-ATP concentration is critical to ara-CTP enhancement. On the basis of these in vitro findings. a combination-chemotherapy regimen consisting of fludarabine, ara-C, and granulocyte colony-stimulating factor, designated as FLAG, has been developed for clinical use $[20,21]$. This regimen and similar regimens further combined with an anthracycline have been safely used to achieve a nearly $50 \%$ rate of complete remission in patients with chemoresistant acute myeloid leukemia [22-25].

Not all patients with refractory or relapsed acute mycloid leukemia respond to FLAG therapy, however, because some leukemic cells acquire drug resistance, including resistance to the key agent, ara-C. Resistance to ara-C in leukemic cells primarily involves a reduction in the intracellular concentration of ara-CTP [8-14]. The mechanisms responsible for the decrease in the ara-CTP concentration include reduced drug uptake and decreased deoxycytidine kinase activity. Increased cytidine deaminase and cytosolic 5 -nucleotidase II activities also contribute to ara-C resistance [26-28]. Because F-ara-A and ara-C share the same pathway for cellular uptake and subsequent phosphorylation, most mechanisms responsible for ara-C resistance also decrease $F$-ara-ATP production [29-31]. If so, $\mathrm{F}$-ara-A-mediated enhancement of ara-CTP production might be compromised in patients with chemoresistant leukemia. Overcoming this limitation requires a better understanding of the biochemical interaction between ara- $\mathrm{C}$ and $\mathrm{F}$-ara-A in the context of ara-C resistance.

The present investigation evaluated the in vitro effect of F-ara- $A$ and ara-C in combination on 2 ara-C-resistant leukemic cell lines. Specifically, we studied the modulation effects of F-ara-A on dCTP and ara-CTP concentrations and on subsequent cytotoxicity.

\section{Materials and Methods}

\subsection{Chemicals and Reagents}

Ara-C, F-ara-A, and nitrobenzylthioinosine (NBMPR) were purchased from Sigma-Aldrich (St. Louis, MO, USA). $\left[5-{ }^{3} \mathrm{H}\right.$ ]ara-C $(30 \mathrm{Ci} / \mathrm{mmol})$ was purchased from Daiichi Pure Chemicals (Tokyo, Japan). Inosine 5'-monophosphate (IMP) labeled with $\left[8-{ }^{14} \mathrm{C}\right] \mathrm{IMP}(45-60 \mathrm{mCi} / \mathrm{mmol})$ was purchased from Moravek Biochemicals (Brea, CA, USA). Tetrahydrouridine was purchased from Calbiochem (La Jolla, CA, USA). $L-(+)$-rhamnose, $\mathrm{NaIO}_{4}$, and methylamine were purchased from Nacalai Tesque (Kyoto, Japan). All other chemicals were of analytic grade.

\subsection{Development of Ara-C-Resistant Leukemic Cell Lines}

Human leukemia HL-60 cells were cultured in RPMI 1640 media supplemented with $10 \%$ heat-inactivated fetal bovine serum at $37^{\circ} \mathrm{C}$ in humidified air containing $5 \%$ carbon dioxide. To develop ara-C-resistant HL-60 variants, we cultured parental HL-60 cells independently in 2 separate flasks in media containing ara- $\mathrm{C}$. The initial ara-C concentration was half the $50 \%$-growth-inhibitory concentration $\left(\mathrm{IC}_{50}\right)$ of HL-60 cells. The cultures were observed daily and allowed to grow. Drug concentrations were gradually increased on subsequent passages, and a single ara-C-resistant cell line was cloned from each flask by the limiting-dilution method. The 2 independent ara-C-resistant HL-60 variants were named $\mathrm{R} 1$ and R2.

\subsection{Proliferation Assay}

To evaluate the proliferation of each cell line, we seeded medium with HL-60, R1, and R2 cells at a density of $1 \times 10^{5} / \mathrm{mL}$, allowed them to grow, and counted cell numbers every 24 hours up to 72 hours by means of the trypan blue dye-exclusion assay. The growth-inhibitory effect of nucleoside analogues was evaluated with the sodium $3^{\prime}-(1-[$ (phenylamino)-carbonyl3,4-tetrazolium])-bis(4-methoxy-6-nitro)benzene sulfonic acid hydratc (XTT) assay according to the manufacturer's instructions (Roche Diagnostics, Indianapolis, IN, USA) [32]. In brief, we incubated $1 \mathrm{~mL}$ of cells $\left(5 \times 10^{4} / \mathrm{mL}\right)$ for 24 hours in a 24-well plate and then added a $10-\mu \mathrm{L}$ aliquot of different concentrations of ara-C or F-ara-A. The cells were incubated for the next 72 hours, and a $100-\mu \mathrm{L}$ aliquot was transferred to a 96-well microplate. The cells then were mixed with $50 \mu \mathrm{L} \mathrm{XTT} \mathrm{and}$ incubated for another 4 hours at $37^{\circ} \mathrm{C}$. Spectrophotometry analysis was performed at an absorbance of $480 \mathrm{nM}$ with a fluorescence microplate reader, (SpectraMax 250; Molecular Devices Japan, Ashiya, Japan). The $\mathrm{IC}_{50}$ value was extrapolated from a growth-inhibition curve produced for each drug.

\subsection{Determination of Intracellular Production of Analogue Triphosphates}

To evaluate the intracellular production of ara-CTP and F-ara-ATP, we incubated HL-60, R1, and R2 cells $(1 \times$ $10^{6} / \mathrm{mL}, 10 \mathrm{~mL}$ ) with different concentrations of ara-C or F-ara-A for discrete intervals. To a cell pellet $\left(1 \times 10^{7}\right.$ cells $)$ obtained by centrifugation $(14,900 \mathrm{~g}, 20$ seconds), we added $30 \mu \mathrm{L}$ of $15 \%$ perchloric acid. The sample was vortexed, cooled in an ice bath for 15 minutes, and centrifuged again $\left(15,000 \mathrm{~g}, 30\right.$ seconds at $\left.4^{\circ} \mathrm{C}\right)$. The supernatant was neutralized with potassium hydroxide and obtained as an acidsoluble fraction, the nucleotide pool [11]. The acid-soluble fraction was applied to an ion-exchange column (TSK-Gel 
DEAE-2 SW, $250-\mathrm{mm}$ length $\times$ 4.6-mm inside diameter; Tosoh, Tokyo, Japan) for high-performance liquid chromatography (HPLC). Elution was carried out at ambient temperature with $0.05 \mathrm{M} \mathrm{Na}_{2} \mathrm{HPO}_{4}(\mathrm{pH} \mathrm{6.9)/20 \%}$ acetonitrile at a constant flow rate of $0.7 \mathrm{~mL} / \mathrm{min}$. Ara-CTP and F-ara-ATP peaks were identified separately under the same HPLC conditions [33] and quantitated by the peak areas at absorbances of $269 \mathrm{~nm}$ and $261 \mathrm{~nm}$, respectively. The values were expressed as pmol $/ 10^{7}$ cells. The packed cell volume $\left(1 \times 10^{7}\right.$ HL- 60 cells $)$ was measured in triplicate to determine the micromolar concentration for comparing the present data with historical controls.

\subsection{Nucleoside-Transport Capacity}

To evaluate the capacity of the membrane nucleoside transporter, we quantified nucleoside analogue uptake in all cell lines by the method of Wiley et al, with slight modifications [3]. In brief, cells $\left(1 \times 10^{7} / \mathrm{mL}, 1 \mathrm{~mL}\right)$ were incubated for 5 minutes at $20^{\circ} \mathrm{C}$, followed by pulse treatment with I $\mu \mathrm{M}$ tritiated ara-C (specific activity, $15 \mu \mathrm{Ci} / \mu \mathrm{mol}$ )) for 60 seconds. The samples were quickly overlaid on oil $(300 \mu \mathrm{L})$ in a microcentrifuge tube and centrifuged $(14.900 \mathrm{~g}, 20$ seconds at $4^{\circ} \mathrm{C}$ ) to terminate the reaction. The supernatant and oil interface were completely removed. The cell pellet was mixed with $1 \mathrm{~mL} 0.5 \mathrm{~N}$ sodium hydroxide for 12 hours at $45^{\circ} \mathrm{C}$ to solubilize the pellet. Sample radioactivities were measured with a scintillation counter on the following day. Nonfacilitated drug uptake was determined in the presence of $3 \mu \mathrm{M}$ NBMPR, which interferes with the membrane nucleoside transporter. The capacity of the transporter was determined as the difference in drug uptake in the absence and presence of NBMPR.

\subsection{Measurement of Deoxycytidine Kinase and Cytosolic 5'-Nucleotidase II}

Deoxycytidine kinase activity was assayed as previously described, with slight modifications [34]. In brief, we obtained crude enzyme by sonicating cells suspended in $100 \mu \mathrm{L} 50 \mathrm{mM}$ Tris- $\mathrm{HCl}(\mathrm{pH} \mathrm{8.0)}$ containing 50\% glycerol and then clarifying the enzyme preparation by centrifugation $(100,000 \mathrm{~g}$, 60 minutes at $4^{\circ} \mathrm{C}$ ). The enzyme $(20 \mu \mathrm{L})$ was incubated for 30 minutes at $37^{\circ} \mathrm{C}$ in a reaction buffer (total volume, $60 \mu \mathrm{L}$ ) containing $20 \mu \mathrm{M}\left[5-{ }^{3} \mathrm{H}\right]$ ara-C (specific activity, $500 \mu \mathrm{Ci} / \mu \mathrm{mol}$ ), $40 \mathrm{mM}$ Tris- $\mathrm{HCl}$ (pH 8.0), $10 \mathrm{mM} \mathrm{MgCl}$, $10 \mathrm{mM}$ adenosine $5^{\prime}$-triphosphate (ATP). $12.5 \mathrm{mM}$ dithiothreitol, and $1 \mathrm{mM}$ tetrahydrouridine. The reaction was terminated by placing the sample in an ice bath. A $10-\mu \mathrm{L}$ aliquot of the sample was spotted on a cellulose thin-layer chromatography sheet (Polygram Cel $300 \mathrm{UV}_{254}, 20 \mathrm{~cm} \times$ $20 \mathrm{~cm} \times 0.1 \mathrm{~mm}$; Macherey-Nagel, Düren, Germany) and developed for 3 hours with solvent (water-2-propanol-acetic acid, 1:2:2 vol/vol). The plate was cut into $1-\mathrm{cm}$ strips, which were then put in scintillation vials filled with $10 \mathrm{~mL}$ Clear-sol 1 (Nacalai Tesque). Radioactivity was counted on the following day. Enzyme activity was expressed in picomoles per hour per milligram protein.

The activity of cytosolic 5'-nucleotidase II was measured as previously described, with slight modifications [30]. The enzyme $(20 \mu \mathrm{L})$ obtained as described above was mixed with reaction buffer (total volume, $60 \mu \mathrm{L}$ ) containing $50 \mathrm{mM}$ imidazole ( $\mathrm{pH} 7.5$ ). $50 \mathrm{mM} \mathrm{NaCl}, 10 \mathrm{mM} \mathrm{MgCl}, 0.5 \mathrm{~g} / \mathrm{L}$ bovine serum albumin, $0.2 \mathrm{mM} \alpha, \beta$-methylene adenosine diphosphate (which inhibited the activity of membrane-bound 5 -ectonucleotidase), $5 \mathrm{mM} \beta$-glycerophosphate, $100 \mu \mathrm{M}$ EGTA, and $200 \mu \mathrm{M}$ IMP and $\left[8-{ }^{14} \mathrm{C}\right] \mathrm{IMP}$ (specific activity. $500 \mu \mathrm{Ci} / \mu \mathrm{mol})$. ATP $(3 \mathrm{mM})$ was added to activate cytosolic 5 -nucleotidase II. The reaction was allowed to continue for 30 minutes at $37^{\circ} \mathrm{C}$ and terminated by placing the sample in an ice bath. A $10-\mu \mathrm{L}$ aliquot of the sample was applied to a thin-layer chromatographic sheet as described above. Enzyme activity was expressed in picomoles per minute per milligram protein.

\subsection{Determination of $d C T P$ Concentration}

To determine the intracellular dCTP concentration, we extracted the acid-soluble fraction as described above and subjected the extract to the periodate-oxidation procedures originally described by Garrett and Santi [35]. In brief, the acid-soluble fraction was mixed with $20 \mu \mathrm{L} 0.5 \mathrm{M} \mathrm{NaIO}_{4}$ and $50 \mu \mathrm{L} 4 \mathrm{M}$ methylamine ( $\mathrm{pH}$ adjusted to 7.5 with phosphoric acid), and incubated for 30 minutes at $37^{\circ} \mathrm{C}$ to degrade ribonucleotides. The sample then was added to $10 \mu \mathrm{L} 1 \mathrm{M}$ rhamnose and put in an ice bath for 15 minutes to remove the $\mathrm{NaIO}_{4}$. The mixture was applied to an HPLC column as described above. and the dCTP concentration (pmol $/ 10^{7}$ cells) was quantitated by its peak area at an absorbance of $254 \mathrm{~nm}$ [33].

\subsection{Biochemical Interaction between Ara-C and F-ara-A}

To determine the effect of $\mathrm{F}$-ara-A, we preincubated HL-60, R1, and R2 cells $\left(1 \times 10^{6} / \mathrm{mL}, 10 \mathrm{~mL}\right)$ with $10 \mu \mathrm{M}$ F-ara-A for 3 hours, washed the cells, resuspended them in fresh media, and further incubated the cells with $10 \mu \mathrm{M}$ ara$\mathrm{C}$ for 3 hours. The cells were washed to terminate the reaction and resuspended again in fresh media. Intracellular ara-CTP and dCTP concentrations were determined immediately by HPLC, and cell proliferation was evaluated with the XTT assay after 72 hours.

\subsection{Statistical Analyses}

Nonparametric Mann-Whitncy $U$ tests were performed with Stat View 5.0 software (Abacus Concepts, Berkeley, CA, USA), and all graphs were generated with GraphPad Prism (version 4.0; GraphPad Software, San Diego, CA, USA). A $P$ level of $\leq .05$ was defined as statistically significant.

\section{Results}

\subsection{Development of 2 Ara-C-Resistant HL-60 Variants and Measurement of Intracellular Ara-CTP Concentrations}

The $\mathrm{IC}_{50}$ values for ara-C in HL-60 cells and cells of the 2 ara-C-resistant variants ( $R 1$ and $R 2$ ) were compared. The 

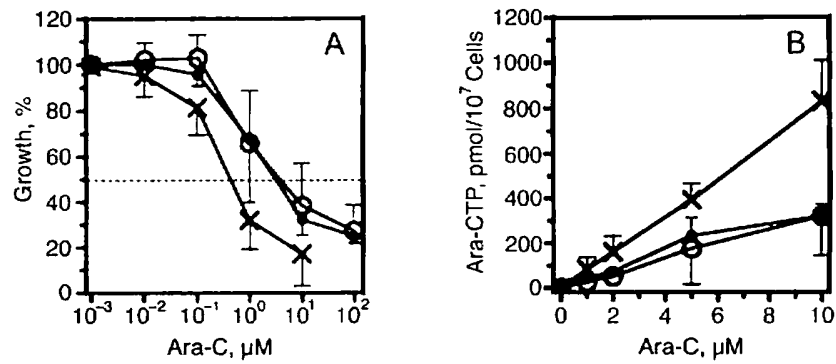

Figure 1. A, Growth-inhibition effect of cytarabine (ara-C) on HL-60 cells and 2 ara-C-resistant variants ( $R \mid$ and $R 2$ ). Cells were incubated for 72 hours with or without different concentrations of ara-C. Proliferation was determined with the XTI assiy. Values are presented as the mean \pm SD of at least 3 independent experiments for HL-60 (X), R1 (•), and $\mathrm{R} 2(\mathrm{O})$ cells. $\mathrm{B}$, Int racellular concentrations of ara-C. 5 '-triphosphatle (ara-CTP). HL-60, RI, and R2 cells were incubated for 6 hours with ara$\mathrm{C}(0,1,2,5$, or $10 \mu \mathrm{M})$. followed hy nucleotide pool extraction and subsequent measurement of ara-(T'P. Values are presented as the mean \pm SD of at least 3 independent experiments for HIL-60) (X), R1 (•), and $\mathrm{R} 2(\mathrm{O})$ cells.

XTT assay demonstrated that R1 and R2 cells were comparably more ara-C resistant than $\mathrm{HL},-60$ ) cells (Figure $1 \mathrm{~A}$. Table 1). The magnitude of the ara-C resistance in these cells was relatively low and might be clinically relevint. The growth rates of the cell lines were similar (Table 1), suggesting that resistance to this $S$ phase-specific drug was not attributable to the speed of the cell cycle. When the cells were incubated with ara-C, intracellular ara-CTP production was increased in a concentration-dependent manner in all cell lines (Figure 1B). During a 6-hour incubation with $10 \mu \mathrm{M}$ araC, HL-60 cells produced more ara-CTP $\left(830 \mathrm{pmol} / 10^{7} \mathrm{cells}\right)$ than $\mathrm{R} 1$ cells $\left(322 \mathrm{pmol} / 10^{7}\right.$ cells; $P=.025$, Mann-Whitney $U$ test) and R2 cells (321 pmol/10 $0^{7}$ cells; $P=.05$, Mann-Whitncy $U$ test) (Figure 1B). R1 and R2 cells were similar with respect to Ara-CTP production. Intracellular ara-CTP concentration appeared to correlate with the magnitude of ara-C resistance (Figure 1).

\section{Table 1.}

Drug Sensitivities of HL-60 and 2 Cytarabine (Ara-C)-Resistant Variants (R1 and R2) to Ara-C*

\begin{tabular}{lccc}
\hline & & \multicolumn{2}{c}{ Ara-C } \\
\cline { 3 - 4 } & $\begin{array}{c}\text { Doubling } \\
\text { Time, } \mathrm{h}\end{array}$ & $\mathrm{IC}_{50}$ & $\begin{array}{c}\text { Relative } \\
\text { Resistance }\end{array}$ \\
\hline HL-60 cells & 14.2 & $\mu \mathrm{M}$ & \\
R1 cells & 13.5 & 3.2 & 8 \\
R2 cells & 13.1 & 4.0 & 10 \\
\hline
\end{tabular}

${ }^{*} \mathrm{HL}-60, \mathrm{R} 1$, and $\mathrm{R} 2$ cells were incubated with various ara-C concentrations for 72 hours and evaluated for proliferation with the XTT assay. The $50 \%$-inhibitory concentration $\left(I C_{50}\right)$ is the mean of at least 3 independent experiments. The relative resistance value was obtained by dividing the $I C_{50}$ values for $R 1$ and $R 2$ cells by the $I C_{50}$ value for $H L-60$ cells. Doubling time was determined with the trypan blue dye-exclusion assay.

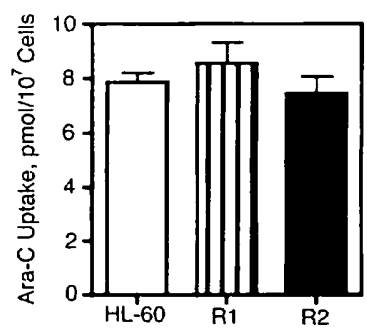

Figure 2. The capacity of the membrane nucleoside transporter in HL60, R1, and R2 cells. After pulse treatment with $1 \mu \mathrm{M}$ tritiated cytarabine (ara-C) for 60 seconds, drug uptake was determined by scintillation counting. Values are presented as the mean \pm SD of at least 3 independent experiments.

\subsection{Membrane Nucleoside-Transport Cupacity}

To elucidate the mechanisms of ara-C resistance, we determined the capacity of the membrane nucleoside transporter. When cells were pulsed with ara-C, the drug was rapidly incorporated in all 3 cell lines (Figure 2). Analogue uptakes in HL-60, R1, and R2 cells were similar (Figure 2), suggesting that the membrane nucleoside-transport capacity was not associated with the development of ara-C resistance.

\subsection{Deoxycytidine Kinase and Cytosolic 5'-Nucleotidase II}

To further elucidate the mechanisms of ara-C resistance, we assayed both deoxycytidine kinase and cytosolic 5 -nucleotidase II activities. Deoxycytidine kinase activity wiss lower in R1 and R2 cells than in HL-60 cells $(P=$ .1495, R1 versus HL-60; $P=.0495, \mathrm{R} 2$ versus HL-60; MannWhitney $U$ lests) (Figure 3A). This lower activity might be responsible for reduced ara-CTP production. The similar kinasc activities in $\mathrm{R} 1$ and $\mathrm{R} 2$ cells $(P=.52$, Mann-Whitney $U$ test) might reflect the comparably reduced ara-CTP production in these 2 cell lines. Cytosolic 5 -nucleotidase II activities in HL-60 and $\mathrm{R} 1$ cells were the same $(P=.51$, Mann-Whitney $U$ test), whereas the enzyme activity of R2 cells was higher than that of HL-60 cells $(P=.021$, MannWhitney $U$ test $)$ and $\mathrm{R} 1$ cells $(P=.049$. Mann-Whitney $U$ lest; Figure 3B). Thus, we demonstrated reduced deoxycytidine kinase activity in $\mathrm{R} 1$ and $\mathrm{R} 2$ cells and increased cytosolic 5'-nucleotidase II activity in R 2 cells. Table 2 summarizes the mechanisms of ara-C resistance in the 2 resistant variants.

\subsection{Sensitivity to F-ara-A and Measurement of Intracellular F-ara-ATP Concentrations}

We compared F-ara-A $\mathrm{IC}_{50}$ values for $\mathrm{HL}-60, \mathrm{Rl}$, and $\mathrm{R} 2$ cells. Both ara-C-resistant variants showed crossresistance to F-ara-A: however, $\mathrm{R} 2$ cells were more $\mathrm{F}$-ara- $\mathrm{A}$ resistant than $R 1$ cells despite similar degrees of ara-C resist- 

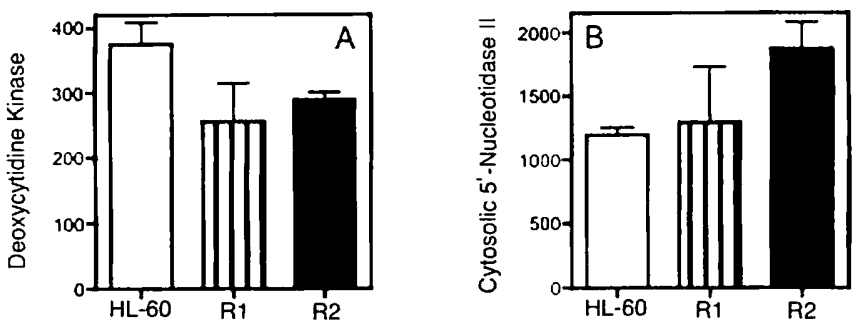

Figure 3. Deoxycytidine kinase (A) and cytosolic 5'-nucleotidase II (B) activities. Deoxycytidine kinase activity was determined in cell extracts from HL-60 and the resistant variants (R1, R2) with cytarabine (ara-C) as a substrate and is expressed in picomoles per hour per milligram protein. Cytosolic $5^{\prime}$-nucleotidase II activity was determined in the HL-60 and resistant variants (R1, R2) cell lines with inosine $5^{\prime}$-monophosphate as a substrate in the presence of adenosine $5^{\prime}$-triphosphate and is expressed in picomoles per minute per milligram protein.

ance (Figure 4A, Table 3). When cells were incubated with $\mathrm{F}$-ara-A, intracellular F-ara-ATP production was increased in a concentration-dependent manner in all cell lines (Figure $4 \mathrm{~B}$ ). During a 3-hour incubation with $10 \mu \mathrm{M}$ F-ara-A, HL-60) cells produced more F-ara-ATP (33. pmol/10 $0^{7}$ cells) than R1 cells (267 pmol $/ 10^{7}$ cells; $P=.049$, Mann-Whitney $U^{\prime}$ test $)$ and R2 cells ( $77 \mathrm{pmol} / 10^{7}$ cells; $P=.049$. Mann-Whitney $U$ test) (Figure 4B). F-ara-ATP production by R1 cells was greater than by $\mathrm{R} 2$ cells $(P=.049$, Mann-Whitney $U$ test), suggesting that the ability to accumulate F-ara-ATP varied despite comparable reductions in ara-CTP concentration in these 2 cell lines. Cytosolic $5^{\prime}$-nucleotidase II is purine specific and has recently been reported to show a very low activity with ara$\mathrm{C}$ monophosphate [36,37]. Enhanced nucleotidase activity might dephosphorylate F-ara-A monophosphate more elficiently than ara-C monophosphate, thereby leading to a lower production of F-ara-ATP by R2 cells. Thus, R2 cells with an increased cytosolic $5^{\prime}$-nucleotidase II activity accumulated a smaller amount of F-ara-ATP, which led to the greater magnitude of $\mathrm{F}$-ara-A resistance compared with R1 cells (Figure 4 ).

\subsection{Alteration of Intracellular $d C T P$ and Ara-CTP Concentrations and Enhancement of Ara-C Cytotoxicity by F-ara-A}

To determine the effect of the combination of F-ara-A and ara-C on ara-C-resistant leukemic cells, we incubated

Table 2.

Mechanisms of Cytarabine (Ara-C) Resistance

\begin{tabular}{|c|c|c|c|}
\hline & $\begin{array}{l}\text { Deoxycytidine } \\
\text { Kinase }\end{array}$ & $\begin{array}{c}\text { Cytosolic } \\
5^{\prime} \text {-Nucleotidase II }\end{array}$ & Uptake * \\
\hline R1 & $\downarrow$ & $\rightarrow$ & $\rightarrow$ \\
\hline $\mathrm{R} 2$ & $\downarrow$ & $\uparrow$ & $\rightarrow$ \\
\hline
\end{tabular}
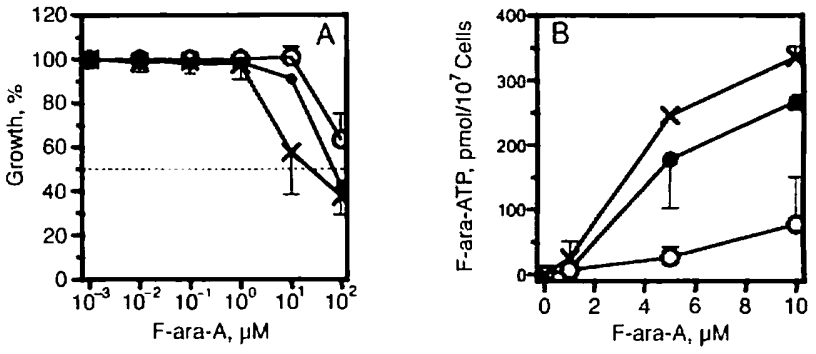

Figure 4. A. Growth inhibition of fludarabine nucleoside (F-ara-A) on HL-60 cells and 2 cytarabine (ara-C)-resistant variants ( $R 1$ and $R 2$ cells). Cells were incubated with or without $F$-ara-A at different concentrations for 72 hours. Proliferation was determined with the XTV assay. Values are presented as the mean $\pm S D$ of at least 3 independent experiments for HL-60 (X), RI (•), and R2 (O) cells. B, Intracellular fludarabine 5'triphosphate ( $F$-ara-ATP) concentrations. HL-60, R1, and $R 2$ cells were incubated for 3 hours with F-ara-A $(0,1,5$, or $10 \mu \mathrm{M})$, followed by nucleotide pool extraction and subsequent measurement of F-ara-ATP. Values are presented as the mean $\pm S D$ of at least 3 independent experiments for $\mathrm{HI},-60(\mathrm{X}), \mathrm{R} 1(\bullet)$, and $\mathrm{R} 2(\mathrm{O})$ cells.

HL-60, R1, and R2 cells with $10 \mu \mathrm{M}$ F-ara-A for 3 hours, followed by washing in fresh media and subsequent incubation with $10 \mu \mathrm{M}$ ara-C for 3 hours. F-ara-A pretreatment reduced the dCTP concentration by $40 \%$ in HL-60 cells (Figure $5 \mathrm{~A}$ ) and augmented ara-CTP production 1.8-fold (Figure 5B). F-ara-A pretreatment was more cytotoxic than ara- $\mathrm{C}$ alone, with cell viability reduced from $68 \%$ to $48 \%$ (a $29 \%$ reduction) $(P=.05$, Mann-Whitney $U$ test: Figure $5 \mathrm{C})$. A 3-hour incubation with $10 \mu \mathrm{M} F$-ara-A alone minimally inhibited cell growth (data not shown). The results suggested that the ari-CTP augmentation was directly associated with the enhancement of the growth-inhibitory effects of ara- $C$ in ara-C-sensitive HL-60 cells.

In R1 cells, preincubation with $10 \mu \mathrm{M}$ F-ara-A similarly reduced the $\mathrm{dCTP}$ level by $33 \%$ (Figure $5 \mathrm{~A}$ ) and increased ara-CTP production 1.9-fold (Figure 5B). The subsequent cytotoxicity also was enhanced, with the viability reduced from $90 \%$ to $66 \%$ (a $27 \%$ reduction) $(P=.05$, Mann-Whitney $U$ test; Figure $5 \mathrm{C}$ ). The equipotent enhancement of cytotoxicity in HL-60 and R1 cells might be attributed to comparably augmented ara-CTP production. In $\mathrm{R} 2$ cells, preincubation with $10 \mu \mathrm{M}$ F-ara-A did not alter dCTP and ara-CTP concentrations (Figures $5 \mathrm{~A}$ and $5 \mathrm{~B}$ ). Cytotoxicity was not enhanced by $F$-ara- $A$ in $R 2$ cells, a result that might be due to the unstimulated ara-CTP production.

The packed cell volume of $1 \times 10^{7} \mathrm{HL}-60$ cells was $21.2 \pm$ $0.9 \mu \mathrm{L}$ (mean $\pm \mathrm{SD}$ of 3 independent determinations). Therefore, the F-ara-ATP concentrations produced by 10 $\mu \mathrm{M} \mathrm{F}$-ara-A in HL-60 and R1 cells (335 and $267 \mathrm{pmol} / 10^{7}$ cells. respectively) were equivalent to concentrations of 12 to $16 \mu \mathrm{M}$. These F-ara-ATP concentration values are consistent with concentrations $(\geq 10 \mu \mathrm{M})$ previously shown to maximally augment ara-CTP production in acute myeloid leukemia blasts [38]. However, the F-ara-ATP concentration produced in $\mathrm{R} 2$ cells was $3.6 \mu \mathrm{M}$ (77 pmol/10 $)^{7}$ cells), which did not surpass this threshold. 
Table 3.

Drug Sensitivities of HL-60 and 2 Cytarabine (Ara-C)-Resistant Variants (R1 and R2) to Fludarabine Nucleoside (F-ara-A)*

\begin{tabular}{lcc} 
& & F-ara-A \\
& $I C_{50} \mu M$ & Relative Resistance \\
\hline HL-60 cells & 22.0 & \\
R1 cells & 70.0 & 3.5 \\
R2 cells & $>100.0$ & - \\
\hline
\end{tabular}

*HL-60, R1, and R2 cells were incubated with various $\mathrm{F}$-ara-A concentrations for 72 hours and evaluated for proliferation with the XTT assay. The $50 \%$-inhibitory concentration $\left(I C_{50}\right)$ was determined as the mean of at least 3 independent experiments. The relative resistance value was obtained by dividing the $I C_{50}$ values for $R 1$ and $R 2$ cells by the $I C_{50}$ value for $\mathrm{HL}-60$ cells. The F-ara-A $I_{50}$ value was not determined for $R 2$ cells because of the limited solubility of F-ara-A.

Thus, $\mathrm{F}$-ara-A-mediated potentiation of ara-C cytotoxicity was compromised in ara-C-resistant $\mathrm{R} 2$ cells, with reduced F-ara-ATP accumulation due to increased cytosolic 5 -nucleotidasc II activity.

\section{Discussion}

Overcoming resistance to ara-C would offer new strategies for the treatment of acute myeloid leukemia. The present study examined the interaction between ara-C and F-ara-A, the biochemical rationale for FLAG chemotherapy. on 2 ara-C-resistant leukemic cell lines, with the focus on changes in intracellular dCTP and ara-CTP concentrations and enhancement of growth inhibition. The eflectiveness of this combination was viewed from the perspective of ari- $C$ resistance mechanisms.

Ara-C-resistant HL-60) variants $R 1$ and $R 2$ were cross-resistant to F-ara-A (Figure 4A, Table 3). Mechanisms of $F$-ara-A resistance include decreased deoxycytidine kinase activity and increased ribonucleotide reductase and cytosolic $5^{\prime}$-nucleotidase II activities [26,29-31]. Changes in deoxycytidine kinase and/or cytosolic 5'-nucleotidase II activities associated with ara-C-resistant variants (Figure 3) would then reasonably be expected to induce cross-resistance to F-ara-A. Nevertheless, R1 and R2 cells exhibited different F-ara-A sensitivities despite similar degrees of ara-C resistance (Figures $1 \mathrm{~A}$ and $4 \mathrm{~A}$. Tables 1 and 3 ). This result was closely associated with the varying ability to accumulate F-ara-ATP (Figure 4B) despite comparable reductions in ara-CTP production (Figure 1B). The major difference between $\mathrm{R} 1$ and $\mathrm{R} 2$ cells was the increased activity of cytosolic $5^{\prime}$-nucleotidase II in R2 cells (Figure 3B). Cytosolic $5^{\prime}$-nucleotidase II activity is reportedly associated with ara-C resistance in vitro [26] and reduced clinical efficacy $[39,40]$. The present study confirms that ara-C-resistant leukemic cells can show increased activity of this enzyme. However, cytosolic $5^{\prime}$-nucleotidase II is purine specific and has a minimal effect on ara- $\mathrm{C}$ monophosphate dephosphorylation $[36,37]$. Schirmer et al demonstrated that cladribine-resistant HL-60 cells that possessed increased cytosolic 5 -nucleotidase II activity and intact deoxycytidine kinase activity lacked cross-resistance to gemcitabine and ara$\mathrm{C}$ [41]. This absence was consistent with the purine specificity of the enzyme. Therefore, increased cytosolic 5'-nucleotidase II activity in R2 cells might preferentially degrade F-ara-A monophosphate over ara-C monophosphate and thereby reduce $F$-ara-ATP accumulation, explaining why $R 2$ cells were more $\mathrm{F}$-ara-A resistant than $\mathrm{R} 1$ cells.

Previous studies demonstrated that F-ara-A pretreatment enhanced the rate of ara-CTP accumulation in a human leukemic cell line in vitro [15]. Clinical studies have confirmed the effectiveness of this combination $[16,17,38]$. The fludarabine-induced increase in the rate of ara-CTP accumulation was dependent on the cellular concentration of F-ara-ATP. and $10 \mu \mathrm{M}$ F-ara-ATP was the threshold for maximizing araCTP augmentation (2-fold increase) in leukemic blasts [38]. In the present study, HL-60 and R1 cells pretreated with $10 \mu \mathrm{M}$ F-ara-A achieved intracellular F-ara-ATP concentrations (12-16 $\mu \mathrm{M}$ ) that exceeded this threshold (Figure 4B). These F-ara-ATP concentrations were also greater than the concentration $(8.5 \mu \mathrm{M})$ needed for the $50 \%$ inhibition of cytidine diphosphate reduction by ribonucleotide reductase in HeLa cells [42]. Accordingly, dCTP was reduced, ara-CTP was augmented (1.8-fold to 1.9-fold increase), and successful potentia-
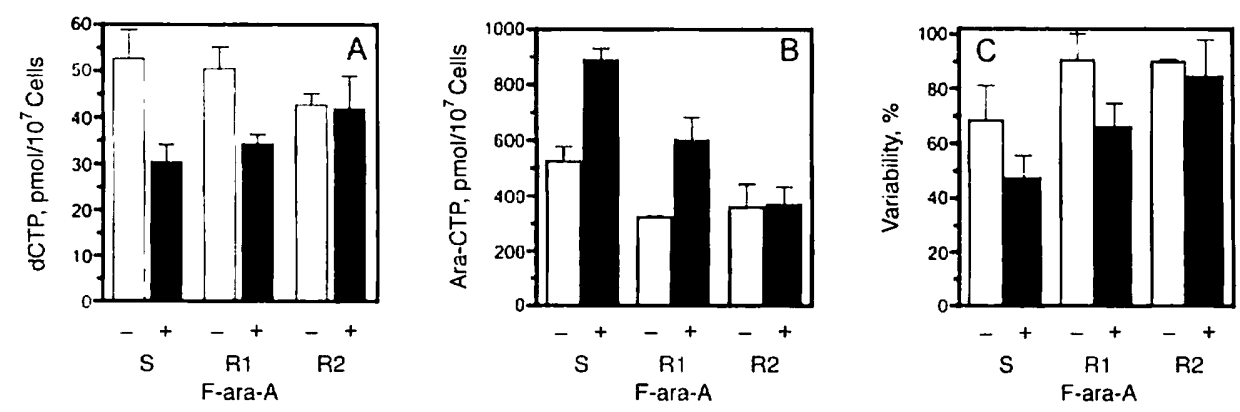

Figure 5. The biochemical interaction between cytarabine (ara-C) and fludarabine nucleoside (F-ara-A). The experimental setting is detailed in "Materials and Methods." The effects of preincubation with (+) and withoul (-) $10 \mu \mathrm{M}$ F-ara-A on intracellular deoxycytidine triphosphate (dCTP) (A) and cytarabine $5^{\prime}$-triphosphate (ara-CTP) (B) concentrations and on subsequent cytotoxicity (C) were evaluated. Values are presented as the mean \pm SD of at least 3 independent experiments. S indicates HL- 60 cells. 
tion of ara-C cytotoxicity was obtained (Figure 5). The degrees of enhanced cytotoxicity in HL-60 and R1 cells were almost identical (Figure 5C), suggesting that F-ara-A could enhance ara- $C$ cytotoxicity despite the ara-C resistance of the cells. In contrast to $\mathrm{R} 1$ cells, no potentiation was observed in $\mathrm{R} 2$ cells (Figure 5); this result might be due to the reduced accumulation of F-ara-ATP to below the threshold. The decreased F-ara-ATP level might be due to an elevation in cytosolic 5'nucleotidase II activity in R2 cells; however, this explanation suggests that intracellular F-ara-ATP concentration varies with the mechanism of ara-C resistance. In this sense, F-araATP could be a surrogate marker for predicting the F-ara$\mathrm{A}-$ mediated potentiation of ara- $\mathrm{C}$ cytotoxicity. Thus, success of the biochemical interaction between ara- $\mathrm{C}$ and $\mathrm{F}$-ara- $\mathrm{A}$ in ara-C-resistant leukemic cells depended on the accumulation of intracellular F-ara-ATP, but it ultimately was associated with the mechanisms of ara-C resistance.

FLAG therapy is effectively used to treat patients with refractory or relapsed acute myeloid leukemia. However, some leukemic blasts might not respond to fludarabinemediated potentiation because ara- $\mathrm{C}$ resistance might collaterally reduce $\mathrm{F}$-ara-ATP production. Our findings thus suggest ways to identify patients who are candidates for combination therapy with ara-C and fludarabine. In vitro testing to determine ara-CTP augmentation by incubating patients leukemic cells with ara-C in the presence and absence of F-ara-A might be conducted prior to initiating chemotherapy.

\section{Acknowledgments}

This work was supported in part by a Grant-in-Aid for Scientific Research from the Ministry of Education, Culture, Sports, Science, and Technology of Japan (C-2, 15590999 , 2003), Grants from the Japan Research Foundation for Clinical Pharmacology (J040000170, J040000189), a Grant from the Nakatomi Foundation for Medicine (J040000585), and a Grant from the University of Fukui $(2004,2005)$. We thank Ms. Mari Miyazaki, Ms. Mari Yamagishi, and Ms. Rie Nishi for their excellent secretarial assistance.

\section{References}

1. Jabbour EJ, Estey E, Kantarjian HM. Adult acute myeloid leukemia. Mayo Clin Proc. 2006;81:247-260.

2. Ferrara F. Unanswered questions in acute myeloid leukaemia. Lancet Oncol. 2004;5:443-450.

3. Wiley JS, Jones SP, Sawyer WH, Paterson AR. Cytosine arabinoside influx and nucleoside tratsport sites in acute leukemia. $J$ Clin Invest. 1982;69:479-489.

4. Furth JJ, Cohen SS. Inhibition of mammalian DNA polymerase by the 5 -triphosphate of 1- $\beta$-D-arabinofuranosylcytosine and the 5 -triphosphate of 9- $\beta$-D-arabinofuranosyladenine. Cancer Res. 1968:28:2061-2067.

5. Inagaki A, Nakamura T, Wakisaka G. Studies on the mechanism of action of 1- $\beta$-D-arabinofuranosylcytosine as an inhibitor of DNA synthesis in human leukemic leukocytes. Cancer Res. 1969:29:2169-2176.

6. Graham FL, Whitmore GF. The effect of 1- $\beta$-D-arabinofuranosylcytosine on growth, viability, and DNA synthesis of mouse L-cells. Cancer Res. 1970;30:2627-2635.

7. Graham FL, Whitmore GF. Studies in mouse L-cells on the incorporation of 1- $\beta-D$-arabinofuranosylcytosine into DNA and on inhibition of DNA polymerase by 1- $\beta$-D-arabinofuranosylcytosine $5^{\prime}$-triphosphate. Cancer Res. 1970;30:2636-2644.

8. Kufe DW, Major PP, Egan EM, Beardsley GP. Correlation of cytotoxicity with incorporation of ara-C into DNA. $J$ Biol Chem. 1980;255:8997-900).

9. Major PP, Egan EM, Beardsley GP, Minden MD, Kufe DW. Lethality of human myeloblasts correlates with the incorporation of arabinofuranosylcytosine into DNA. Proc Natl Acad Sci USA. 1981;78:3235-3239.

10. Kufe D, Spriggs D, Egan EM, Munroe D. Relationships among Ara-CTP pools, formation of (Ara-C)DNA, and cytotoxicity of human leukemic cells. Blood. 1984;64:54-58.

11. Yamauchi $T$, Uedia $T$, Nakamura $T$, $A$ new sensitive method for determination of intracellular 1- $\beta$-D-arabinofuranosylcytosine 5 -triphosphate content in human materials in vivo. Cancer Res. 1996;56:1800-1804.

12. Yamauchi $T$, Kishi S, Kawai $Y$, Ueda T. Pharmacokinetics of intracellular ara-CTP, an active metabolite of ara-C in leukemic cells from patients treated with ara-C including low-dose by a newly established assay |abstract|. Proc Am Soc Clin Oncol. 1998;17:255a.

13. Yamauchi T, Ueda T. A sensitive new method for clinically monitoring cytarabine concentrations at the DNA level in leukemic cells. Biochem Pharmacol. 2005;69:1795-1803.

14. Plunkett W, lacoboni S, Estey E, Danhauser L, Liliemark JO, Keating MJ. Pharmacologically directed ara-C therapy for refractory leukemia. S'min (ncol. 1985;12(suppl 3):20-30.

15. Gandhi V, Plunket W. Modulation of arabinosylnucleoside metabolism by arabinosylnucleotides in human leukemia cells. Cancer Res. 1988;48:329-334.

16. Gandhi V, Kemena A, Keating MJ, Plunkett W. Fludarabine infusion potentiates arabinosylcytosine metabolism in lymphocytes of patients with chronic lymphocytic leukemia. Cancer Res. 1992;52:897-903.

17. Gandhi V, Estey E, Keating MJ, Plunkett W. Fludarabine potentiates metabolism of cytarabine in patients with acute myelogenous leukemia during therapy. I Clin Oncol. 1993;11:116-124.

18. Gandhi V, Plunkett W. Cellular and clinical pharmacology of fludarabine. Clin Pharmacokiner. 2002;41:93-103.

19. Parker WB, Bapat AR, Shen JX, Townsend AJ, Cheng YC. Interaction of 2-halogenated dATP analogs $(\mathrm{F}, \mathrm{Cl}$, and $\mathrm{Br})$ with human DNA polymerases, DNA primase, and ribonucleotide reductase. Mol Pharmacol. 1988;34:485-491.

20. Estey E. Thall $\mathrm{P}$. Andreeff $\mathrm{M}$, et al. Use of granulocyte colonystimulating factor before, during, and after fludarabine plus cytarabine induction therapy of newly diagnosed acute myelogenous leukemia or myelodysplastic syndromes: comparison with fludarabine plus cytarabine without granulocyte colony-stimulating factor. J Clin Oncol. 1994;12:671-678.

21. Gandhi V, Estey E, Du M, Nowak B, Keating MJ, Plunkett W. Modulation of the cellular metabolism of cytarabine and fludarabine by granulocyte-colony-stimulating factor during therapy of acute myelogenous leukemia. Clin Cancer Res. 1995;1:169-178.

22. Clavio M, Carrara $P$, Miglino $M$, et al. High efficacy of fludarabinecontaining therapy (FLAG-FLANG) in poor risk acute myeloid leukemia. Haemalologica. 1996:81:513-520.

23. Jackson G, Taylor P, Smith GM, et al. A multicentre, open, noncomparative phase II study of a combination of fludarabine phosphate, cytarabine and granulocyte colony-stimulating factor in relapsed and refractory acute myeloid leukaemia and de novo refractory anaemia with excess of blasts in transformation. $\mathrm{Br} J$ Haematol. 2001;112:127-137.

24. Steinmetz HT, Schulz A. Staib P, et al. Phase-II trial of idarubicin, fludarabine, cytosine arabinoside, and filgrastim (Ida-FLAG) for treatment of refractory, relapsed, and secondary AML. Ann Hematol. 1999:78:418-425.

25. Virchis A, Koh M, Rankin P, et al. Fludarabine, cytosine arabinoside, granulocyte-colony stimulating factor with or without idarubicin in the treatment of high risk acute leukaemia or myelodysplastic syndromes. Br J Haematol. 2004;124:26-32.

26. Dumontet C, Fibianowska-Majewska K, Mantincic D, et al. Com- 
mon resistance mechanisms to deoxynucleoside analogues in variants of the human erythroleukaemic line K562. Br J Haematol. 1999;106:78-85.

27. Galmarini CM. Mackey JR, Dumontet C. Nucleoside analogues: mechanisms of drug resistance and reversal strategies. Leukemia. 2001; $15: 875-890$.

28. Jamieson GP, Snook MB, Wiley JS. Saturation of intracellular cytosine arabinoside triphosphate accumulation in human leukemic blast cells. Leuk Res. 1990;14:475-479.

29. Bai L, Yamaguchi M, Tatsumi M, Kon K, Brautigam M. Mechanisms responsible for resistance of sublines derived from leukemia cell lines to an antitumor agent 9- $\beta$-D-arabinofuranosyl-2lluoroadenine. J Cancer Res Clin Oncol. 1998;124:367-373.

30. Mansson E, Flordal E, Liliemark J. et al. Down-regulation of deoxycytidine kinase in human leukemic cell lines resistant to cladribine and clofarabine and increased ribonucleotide reductase activity contributes to fludarabine resistance. Biochern Pharmacol. 2003;65:237-247.

31. Yoshio N, Kawai Y, Hori H, Ueda T. Resistance to 9- $\beta$-D-arabinofuranosyl-2-fluoroadenine due to reduced incorporation into DNA from competition by excess deoxyadenosine triphosphate: implications for different sensitivities to nucleoside analogues. Int J Hematol. $2005 ; 81: 405-412$.

32. Jost LM, Kirkwood JM, Whiteside TL. Improved short- and long-term XTT-based colorimetric cellular cytoloxicity assay for melanoma and other tumor cells. J Immunol Methods. 1992;147:153-165.

33. Yamauchi T, Ueda T. Simple and sensitive method for quantification of fludarahine triphosphate intracellular concentration in leukemic cells using isocratic liquid chromatography. I Chromatogr B Analyt Technol Biomed Life Sci. 2004:799:81-86.

34. Takemura H, Urasaki Y. Yoshida A, Fukushima T, Ueda T. Simultancous treatment with 1- $\beta$-D-arabinofuranosylcytosine and daunorubicin induces cross-resistance to both drugs due to a combination-specific mechanism in HL60 cells. Cancer Res. 2001:61:172-177.

35. Garrett C, Santi DV. A rapid and sensitive high pressure liquid chromatography assay for deoxyribonucleoside triphosphates in cell extracts. Anal Biochem. 1979;99:268-273.

36. Mazzon C, Rampazzo C, Scaini MC, et al. Cytosolic and mitochondrial deoxyribonucleotidases: activity with substrate analogs, inhibitors and implications for therapy. Biochem Pharmacol. 2003;66:471-479.

37. Spychala J, Madrid-Marina V, Fox IH. High $\mathrm{K}_{\mathrm{m}}$ soluble $5^{\prime}$-nucleotidase Irom human placenta: properties and allosteric regulation by IMP and ATP. J Biol Chem. 1988;263:18759-18765.

38. Gandhi V. Estey E. Du M, Keating MJ, Plunkett W. Minimum dose of fludarabine for the maximal modulation of 1-beta-D-arabinofuranosylcytosine triphosphate in human leukemia blasts during therapy. Clin Cuncer Res. 1997:3:1539-1545.

39. Galmarini CM, Graham $K$, Thomas $X$, et al. Expression of high $K_{m}$ $5^{\prime}$-nucleotidase in leukemic blasts is an independent prognostic factor in adults with acute myeloid leukemia. Blood. 2001;98:1922-1926.

40. Galmarini CM. Thomas $X$, Calvo $F$, et al. In vivo mechanisms of resistance to cytarabine in acute myeloid leukaemia. Br J Haematol. 2002;117:860-868.

41. Schirmer M. Stegmann AP, Geisen F, Konwalinka G. Lack of crossresistance with gemcitabine and cytarabine in cladribine-resistant HL60 cells with elevated 5'-nucleotidase activity. Exp Hematol. 1998;26:1223-1228.

42. 'Iseng WC. Derse D, Cheng YC, Brockman RW, Bennett LL Jr. In vitro biological activity of 9-beta-D-arabinofuranosyl-2-fluoroadenine and the biochemical actions of its triphosphate on DNA polymerases and ribonucleotide reductase from HeLa cells. $\mathrm{Mol}$ Pharmacol. 1982:21:474-477. 